\title{
$\mathrm{Si}_{3} \mathrm{~N}_{4}$ セラミックスの親油性に及ぼす成分添加 および HP 焼結の影響
}

\author{
加藤浩二* 向井弘治* 徳田太郎 中村省三 木戸光夫
}

広島工業大学工学部機械システム工学科

J. Japan Inst. Metals, Vol. 68, No. 7 (2004), pp. 475-481

(C) 2004 The Japan Institute of Metals

\section{Influence of Component Exerted and Hot Press Sintered on Lipophilic Property of Silicon Nitride Ceramics}

Koji Kato*, Kouji Mukai*, Tarou Tokuda, Syouzou Nakamura and Mitsuo Kido

Department of Mechanical Systems Engineering, Faculty of Technology, Hiroshima Institute of Technology, Hiroshima 731-5193

$\mathrm{Si}_{3} \mathrm{~N}_{4}$ ceramics with added $\mathrm{Fe}_{3} \mathrm{O}_{4}$ and $\mathrm{Mo}$ are often used for sliding parts because of the highly lipophilic properties and selflubricity of these additives. However, flaws are generated by differences in thermal expansion between these additional components and the matrix during sintering. Therefore, materials and processes that improve these mechanical properties are needed.

In this study, such ceramics were hot-pressed to enhance their strength, lipophilic properties and abrasion resistance and compared with atmosphere-sintered $\mathrm{Si}_{3} \mathrm{~N}_{4}$. Micro-lipophilic properties were also considered. The bending strength, relative density, hardness and fracture toughness were all improved by hot-pressing $\mathrm{Si}_{3} \mathrm{~N}_{4}$ ceramics containing $\mathrm{Fe}_{3} \mathrm{O}_{4}$ and Mo. Bending strength was increased by about $430 \mathrm{MPa}$, and density was increased by over 4 percent. Macro and micro-lipophilic properties were enhanced by the presence of $\mathrm{Fe}_{3} \mathrm{O}_{4}, \mathrm{MoO}_{3}$ and $\mathrm{Si}_{2} \mathrm{~N}_{2} \mathrm{O}$ on the material's surface. Abrasion resistance was enhanced by a falling of grains and the presence of self-lubricating $\mathrm{MoO}_{3}$ on the material's surface.

(Received January 6, 2004; Accepted May 14, 2004)

Keywords: silicon nitride ceramics, friction coefficient, wear volume, lipophilic property, tri-Iron tetra-oxide, molybdenum, hot-pressing, oil droplet, atomic force microscope

\section{1. 緒言}

$\mathrm{Fe}_{3} \mathrm{O}_{4}$ および $\mathrm{Mo}$ を添加した $\mathrm{Si}_{3} \mathrm{~N}_{4}$ セラミックスは, 親油 性および自己潤滑性に優れているため, 摺動部品への適用が 図られている1)。しかし，分散相とマトリックス相との間の 熱膨張係数差によって割れが生じ, 強度の低下を招くことが ある。これまで著者らは, $\mathrm{Fe}_{3} \mathrm{O}_{4}, \mathrm{Mo}$ を添加した $\mathrm{Si}_{3} \mathrm{~N}_{4}$ セラ ミックスを常圧焼結により作製し, その機械的特性, 密度, 親油性および摩擦・耐摩耗特性などを調査した。その結果, $\mathrm{Si}_{3} \mathrm{~N}_{4}$ セラミックスの親油性や摩擦・耐摩耗特性は, $\mathrm{Fe}_{3} \mathrm{O}_{4}$ または Mo を添加させることによりいずれも向上するが, 曲 げ強度, 硬さおよび密度は逆に若干低下することを報告2 てきた。

ところで, ホットプレス焼結法 (Hot Press, 以下 HP また は HP 焼結と略称する) は材料の緻密化, 強度の向上に有効 であるとされており ${ }^{3,4)}$, 本研究のように, $\mathrm{Fe}_{3} \mathrm{O}_{4}$ および $\mathrm{Mo}$ を添加させた $\mathrm{Si}_{3} \mathrm{~N}_{4}$ においても，その効果は期待できるもの と考えられる.

そこで本研究では, $\mathrm{Si}_{3} \mathrm{~N}_{4}$ セラミックスの機械的特性のう

\footnotetext{
* 広島工業大学大学院生 (Graduate Student, Hiroshima Institute of Technology)
}

ち, とくに強度の向上を図りつつ, 親油性および摩擦・耐摩 耗特性にも優れた材料の開発・創製を目指し, $\mathrm{Fe}_{3} \mathrm{O}_{4}$ 抢よび $\mathrm{Mo}$ を添加した $\mathrm{Si}_{3} \mathrm{~N}_{4}$ を $\mathrm{HP}$ で作製し, その特性を常圧焼結 法により作製したものと比較・検討した.さらに，前報2) と 同様, 微小な油滴による濡れ性についても種々検討した.

\section{2. 実 験 方 法}

\section{1 試料および試験片}

供試材は, $\mathrm{Si}_{3} \mathrm{~N}_{4}$ 粉末 (宇部興産製, 純度 $99.99 \%$, 平均粒 径 $0.4 \mu \mathrm{m}$ ) に焼結助剤として $\mathrm{Al}_{2} \mathrm{O}_{3}$ および $\mathrm{Y}_{2} \mathrm{O}_{3}$ をそれぞれ 2.83 mass\%ずつ添加させたもの, さらにそれに $\mathrm{Fe}_{3} \mathrm{O}_{4}$ およ び Mo を添加させた数種の材料 (以下, 前者を SN 材, 後者 を $\mathrm{FM}$ 材と略称する) を常圧焼結 ${ }^{12}$ ) および $\mathrm{HP}$ 焼結 (圧力 20 $\mathrm{MPa}$ ，温度 $2073 \mathrm{~K}, 12.4 \mathrm{ks}$ 間保持後炉冷）によって作製し た.なお, $\mathrm{Mo}$ 量を一定とし, $\mathrm{Fe}_{3} \mathrm{O}_{4}$ 量を種々に変化させた 材料 (FM 材)については, その添加量が少ない順に記号 $\mathrm{a}$, $1 \mathrm{~b}, 1 \mathrm{c}$ を付記(例えば $\mathrm{FMa}$ ), $\mathrm{Fe}_{3} \mathrm{O}_{4}$ 量を一定とし, Mo 量を 種々に変化させた材料については, 同じくその添加量が少な い順に記号 $\mathrm{a}, 2 \mathrm{~b}, 2 \mathrm{c}$ を付記, HP 焼結させた材料について は，とくに添字 $\mathrm{HP}$ を付記 (例えば $\mathrm{SN}_{\mathrm{HP}}$ ) して区別してあ る. 得られた焼結体は, 所定寸法に平面研削加工後バフ研磨 によって鏡面仕上げしたが， $\mathrm{FM}_{\mathrm{HP}}$ 材については，FM 材と 
同様に熱処理を施し, 固体潤滑相である $\mathrm{MoO}_{3}$ を形成させ た ${ }^{2)}$.このようにして得られた試験片は，アセトン中で 3.6 $\mathrm{ks}$ 間超音波脱脂洗浄後温風乾燥させ, デシケータ中で一定 時間乾燥後, 順次試験に供した。一方, 供試材の諸特性は, 前報 ${ }^{2)}$ と同様な方法で測定・評価した。な打親油性評価の場 合, 本研究では, 油滴のサイズが $\mathrm{nm}$ オーダーを“ミクロ”, mm オーダーを“マクロ”と略称する.

\section{2 成分の分析法}

材料表面の定性分析を電子プローブマイクロアナライザー (Electron Probe Micro Analyzer，日本電子陎製 JXA-8900R (以下 EPMA と略称) ), $\mathrm{X}$ 線光電子分光分析装置 (X-ray Photoelectron Spectroscopy，島津製作所㧣製 AXIS ULTRA (以下 XPS と略称) ) およびX 線回折装置 (X-ray Diffraction, ブルカー・エイエックスエス侏製 M21X(以下 XRD と略称))を用いて行った. EPMA およびXPSの分析 条件は前報 ${ }^{2)}$ と同様であるが，XRD は励起 X 線源を $\mathrm{Cu}-$

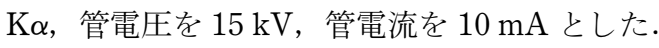

\section{3. 実 験 結 果}

\section{$3.1 \mathrm{HP}$ (ホットプレス) 焼結による諸特性の変化}

Table 1 に $\mathrm{SN}_{\mathrm{HP}}$ 材, $\mathrm{FM}_{\mathrm{HP}}$ 材 $\left(\mathrm{Fe}_{3} \mathrm{O}_{4}: 3.60\right.$ mass $\%$, Mo: 0.90 mass\%)の諸特性を示す。比較材として用いた SN 材, FMa 材の特性も併記してある.なお，それぞれ曲げ強度 $\sigma_{\mathrm{b}}$ は 10 回, 硬さ $H v$ は 30 回, 破壊じん性值 $K_{\mathrm{C}}$ は 30 回, 密 度 $\rho$ は 3 回, マクロな油滴接触角 $\theta_{\mathrm{mac}}$ は 50 回, 摩擦係数 $\mu$ は 5 回以上測定した值の平均值である.これより, $\mathrm{SN}_{\mathrm{HP}}$ 材 の曲げ強度, 密度, 硬さおよび破壊靱性值は, いずれも SN 材より向上していることがわかる，とくに，曲げ強度 $\sigma_{\mathrm{b}}$ は 約 2 倍, 相対密度 $\rho$ は約 $4 \%$ 以上向上している. 一方, $\mathrm{SN}_{\mathrm{HP}}$ 材のマクロな親油性および摺動特性も, $\mathrm{SN}$ 材のそれ らより向上(すなわち, 油滴接触角, 摩擦係数が低下)してい る.さらに, $\mathrm{FM}_{\mathrm{HP}}$ 材も同様に $\mathrm{SN}$ 材より向上している.す なわち, $\mathrm{Si}_{3} \mathrm{~N}_{4}$ の諸特性は, 成分の添加・無添加に関わらず $\mathrm{HP}$ 焼結することにより向上し, $\mathrm{SN}_{\mathrm{HP}}$ 材は機械的特性 (とく に強度)に優れ， $\mathrm{FM}_{\mathrm{HP}}$ 材は親油性および習動特性に優れて いることがわかる。

以上より, $\mathrm{Si}_{3} \mathrm{~N}_{4}$ の機械的特性, 密度, 親油性および摩 擦・耐摩耗特性は HP 焼結によりかなり向上することが判明 した.

Table 1 Properties of material SN, FMa, $\mathrm{SN}_{\mathrm{HP}}$ and $\mathrm{FM}_{\mathrm{HP}}$.

\begin{tabular}{lcccccc}
\hline $\begin{array}{c}\text { Bending } \\
\text { strength } \\
\sigma_{\mathrm{b}} \\
(\mathrm{MPa})\end{array}$ & $\begin{array}{c}\text { Relative } \\
\text { density } \\
(\%\end{array}$ \\
\hline $\mathrm{SN}_{\mathrm{HP}}$ & 1130.39 & $\begin{array}{c}\text { Vickers } \\
\text { herdness } \\
H_{v} \\
(\mathrm{P}=9.8[\mathrm{~N}])\end{array}$ & $\begin{array}{c}\text { Fracture } \\
\text { toughness } \\
K_{c} \\
\left(\mathrm{MPa} \cdot \mathrm{m}^{1 / 2}\right)\end{array}$ & $\begin{array}{c}\text { Contact } \\
\text { angle } \\
\left({ }^{\circ}\right)\end{array}$ & $\begin{array}{c}\text { Friction } \\
\text { coeficient } \\
\mu\end{array}$ \\
\hline $\mathrm{FM}_{\mathrm{HP}}$ & 982.01 & 95.71 & 1461.51 & 7.12 & 4.50 & 0.27 \\
\hline $\mathrm{SN}$ & 675.21 & 94.84 & 1540.67 & 5.23 & 17.91 & 0.53 \\
\hline $\mathrm{FMa}$ & 574.94 & 91.76 & 1438.70 & 6.17 & 13.63 & 0.43 \\
\hline
\end{tabular}

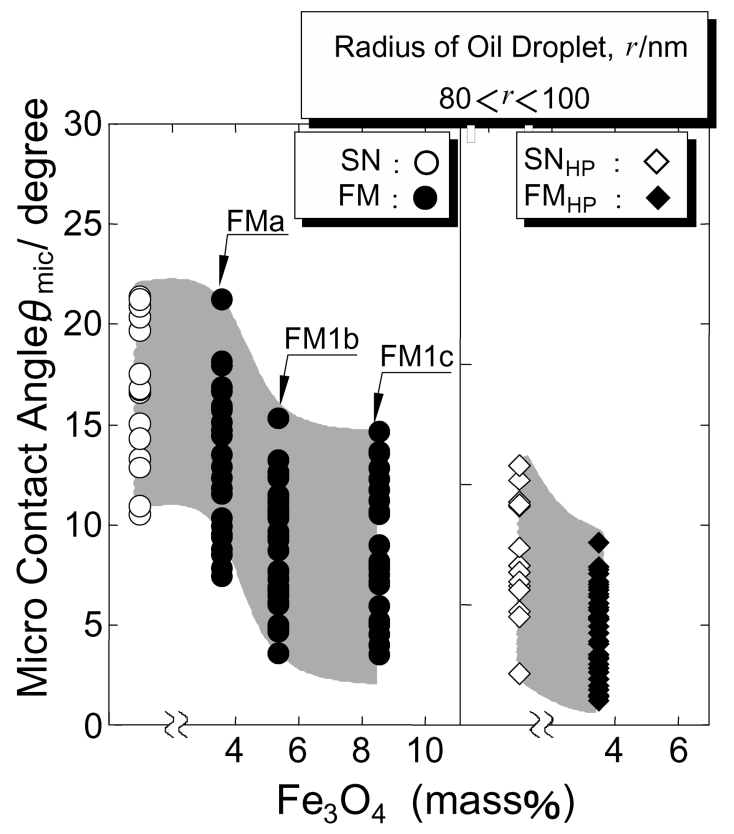

Fig. 1 Change of micro-contact angles of oil droplet in Material $\mathrm{SN}, \mathrm{FM}, \mathrm{SN}_{\mathrm{HP}}$ and $\mathrm{FM}_{\mathrm{HP}}$.

\section{2 ミクロな親油性}

ミクロな領域での濡れ接触角は, 液滴サイズによって変化 する5). すなわち, FM 材のミクロな油滴接触角は, マクロ なそれとは異なり, $\mathrm{SN}$ 材に比べてあまり差がないことの原 因の一つに，ミクロな油滴の大きさにばらつきがあることが 考えられる(油滴の半径は約 $50 \sim 300 \mathrm{~nm})^{2)}$. そこで，こう した影響をできる限り減少させるため, 油滴半径 $r$ が $80 \mathrm{~nm}$ $<r<100 \mathrm{~nm}$ のもを選んでミクロな親油性を評価してみた. Fig. 1 は, $\mathrm{SN}$ 材 (記号○印) FM 材 (記号○印), $\mathrm{SN}_{\mathrm{HP}}$ 材 (記 号〉印) および $\mathrm{FM}_{\mathrm{HP}}$ 材 (記号く印)のミクロな油滴接触角 $\theta_{\text {mic }}$ を AFM で観察・測定したものである(ただし, 同図中 のハッチング部分は抢抢よその傾向線である)。これより, $\mathrm{FM}$ 材のミクロな親油性は $\mathrm{Fe}_{3} \mathrm{O}_{4}$ の増加に伴い, $\mathrm{SN}$ 材より 向上(すなわち, ミクロな油滴接触角が低下)している. 一方, $\mathrm{HP}$ 焼結した $\mathrm{SN}_{\mathrm{HP}}$ 材のミクロな親油性は，同じく $\mathrm{SN}$ 材よ り向上している。 また, $\mathrm{FM}_{\mathrm{HP}}$ 材のミクロな親油性は, $\mathrm{FM}$ 材よりかなり向上しておりきわめて優れていることがわか る.このようなミクロな親油性の向上は, 油滴半径 $r$ が 80 $\mathrm{nm}<r<100 \mathrm{~nm}$ の範囲でとくに顕著であった.

以上より，ミクロな親油性は成分添加や HP 焼結によって かなり向上することがわかった，なお，結果は省略している が, ミクロな油滴接触角は, 僅かではあるがマクロなそれに 比べて低くなる傾向にあった.

\section{4. 考察}

\subsection{HP 焼結による微組織の変化}

$\mathrm{Si}_{3} \mathrm{~N}_{4}$ の機械的特性 (とくに強度), 親油性および摩擦・耐 摩耗特性が HP 焼結により向上した原因を調べるため, 各材 料の組織観察を行った. $\mathrm{FM}$ および $\mathrm{FM}_{\mathrm{HP}}$ 材の代表的な 
SEM 写真を Fig. 2 に示す。これより, HP 焼結した $\mathrm{FM}_{\mathrm{HP}}$ 材は FM 材に比べて大きな気孔(同図 (a)中矢印)が少ない組 織になっていることがわかる，そこで，HP 焼結による気孔 率, 気孔直径 $d$ の変化を調べた. その結果を Table 2 に示 す。ただし, 直径 $d$ は, SEM 像から気孔の縦と横の長さを 測定し平均したものである.これより， HP 焼結した材料 $\left(\mathrm{SN}_{\mathrm{HP}}\right.$ および $\left.\mathrm{FM}_{\mathrm{HP}}\right)$ は常圧焼結した材料 $(\mathrm{SN}$ および $\mathrm{FMa})$ に比べて気孔率が減少し, 直径も小さくなっていることがわ かる. ところで, $\mathrm{Si}_{3} \mathrm{~N}_{4}$ の強度は, 応力集中源となる気孔が 大きく, しかも $\mathrm{Fe}_{3} \mathrm{O}_{4}$ や $\mathrm{Mo}$ 成分の添加量が多い程低下す

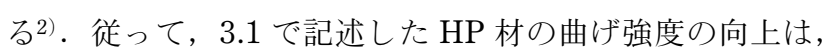
こうした破壊起点となる気孔の微小化(密度の向上)が原因の 一つと考えられる。. また, $\mathrm{FM}_{\mathrm{HP}}$ 材は, FM 材に比べ粗大化 した柱状粒子(同図(b)中矢印)がとくに目立つ組織になって いる. そこで, HP による粒径 $D$ およびアスペクト比の变化 について調べてみた。 それを Fig. 3(a), (b)に示す. 同図
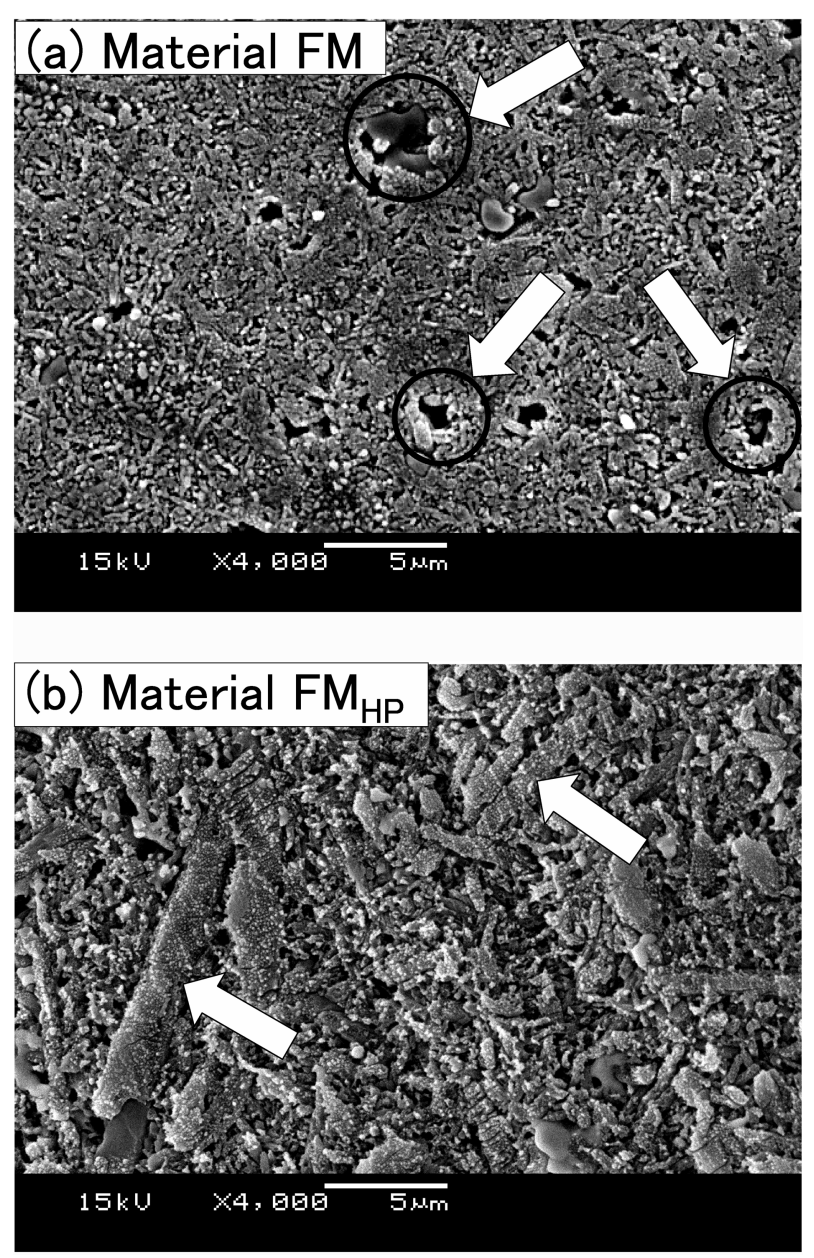

Fig. 2 Surface morphology of Material FM and $\mathrm{FM}_{\mathrm{HP}}$ observed by SEM (Arrows are blow hole and elongation grain).

Table 2 Porosity and diameter of blow hole of material SN, $\mathrm{FMa}, \mathrm{SN}_{\mathrm{HP}}$ andFM $\mathrm{HP}$.

\begin{tabular}{lcccc}
\hline \multicolumn{1}{c}{ Material } & $\mathrm{SN}$ & $\mathrm{FMa}$ & $\mathrm{SN}_{\mathrm{HP}}$ & $\mathrm{FM}_{\mathrm{HP}}$ \\
\hline Porosity, \% & 1.20 & 1.43 & 0.02 & 0.17 \\
\hline Diameter of blow hole, $d / \mu \mathrm{m}$ & 0.28 & 0.34 & 0.06 & 0.10 \\
\hline
\end{tabular}

(a)の D は SEM 観察によって得られた粒子を長方形と近似 させ，その短辺の平均長さを示し，同じく(b)のアスペクト 比は (長辺の長さ)/(短辺の長さ)である.これより, HP 焼 結によって $D$ およびアスペクト比はかなり大きくなってい ることがわかる. 従って, 3.1 で記述した HP 材の破壊じん 性值の向上は, 粒径とアスペクト比が大きくなったことが主 因であると考えられる ${ }^{3,4,7)}$. ところで, 硬さが向上6) した原 因の一つは, HP 焼結による気孔率の低下が考えられる.

摺動特性は HP 焼結することによって向上(すなわち, 摩 擦係数が低下)することを 3.1 では述べた．そこで，HP に よる微組織の変化が耐摩耗性に及ぼす影響についても調査 し, 検討してみた. Fig. 4 は, SN 材 (記号○印) FM 材 (記号 ○印), $\mathrm{SN}_{\mathrm{HP}}$ 材 (記号〉印) および $\mathrm{FM}_{\mathrm{HP}}$ 材 (記号・印)の摩 耗量 $V$ を測定したものである。これより，FM 材の耐摩耗 性は Mo の増加に伴い, SN 材より向上(摩耗量が低下)して いる．これは成分添加 $\left(\mathrm{MoO}_{3}\right)$ により摩擦係数が低下した2) ことが原因の一つと考えられるが, 一方, HP 焼結した $\mathrm{SN}_{\mathrm{HP}}$ 材の耐摩耗性は, 同じく $\mathrm{SN}$ 材より向上している. た, $\mathrm{FM}_{\mathrm{HP}}$ 材の耐摩耗性は, FMa 材のみならず, FM2b, $\mathrm{FM} 2 \mathrm{c}$ および $\mathrm{SN}_{\mathrm{HP}}$ 材より向上していることがわかる.すな わち, 耐摩耗性を向上させるためには成分添加および $\mathrm{HP}$ 焼 結により摩擦係数を低下させることが最も有効であると考え られる. ところで, 硬さの異なるセラミックスが互いに接触 した場合, 硬い方の凸部が, 軟らかい相手を摩耗させる際 に，粒子の脱落を生じることがある ${ }^{9,10)}$. そこで本研究にお

(a)

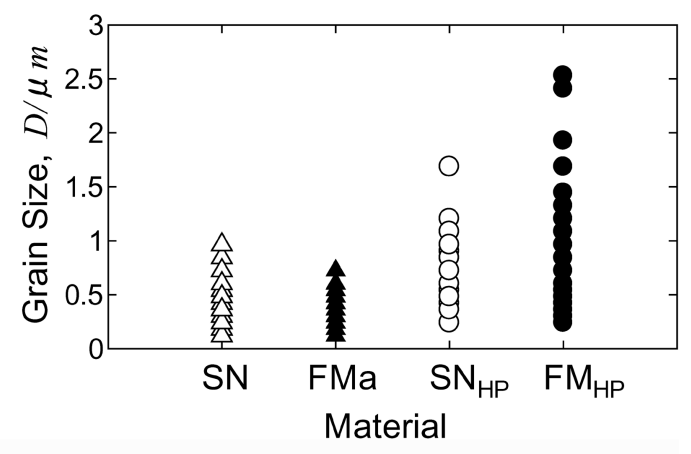

(b)

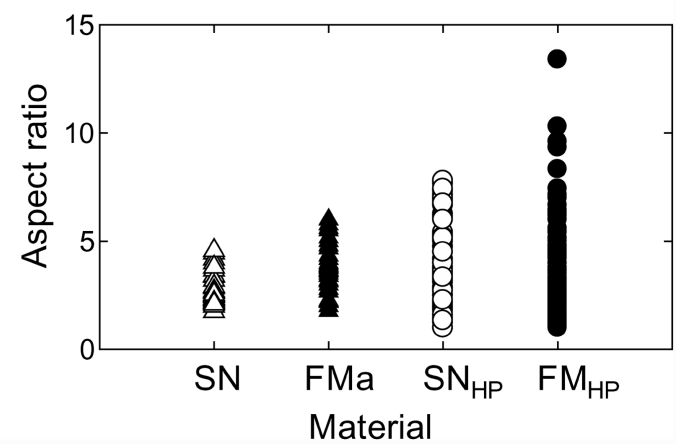

Fig. 3 Grain size and aspect ratio of Material SN, FMa, $\mathrm{SN}_{\mathrm{HP}}$ and $\mathrm{FM}_{\mathrm{HP}}$. 
いても, 摩耗痕の SEM 観察を各材料について行ってみた. FMa 材抢よび $\mathrm{FM}_{\mathrm{HP}}$ 材の代表的な結果を Fig. 5 に示す。こ れより，摩耗痕と見られる大きな穴(直径約 $2.70 \mu \mathrm{m}$ (同図中 矢印))の数は $\mathrm{FM}_{\mathrm{HP}}$ 材の方が $\mathrm{FMa}$ 材より少ないことがわか る.このような穴は, Fig. 2 や Table 2 で示した FM 材の 気孔よりも大きく, しかも摩耗痕の随所に存在しており, 摺 動接触により粒子が脱落した痕である可能性が高いと思われ る.ところで，一般にセラミックスのようなぜい性材料では 硬さや破壊じん性值が高いほど摩耗しにくいことが知られて おり，それらの各関係は次式9)で表わされる。

$$
W=\alpha \frac{E^{7 / 8}}{K_{\mathrm{c}}^{1 / 2} H v^{3 / 2}} P^{9 / 8} x
$$

ここで, $W$ は摩耗量, $\alpha$ は定数, $E$ はヤング率, $K_{\mathrm{c}}$ は破壊 じん性值, $H v$ はビッカース硬さ, $P$ は押し込み荷重, $x$ は 摺動距離である. 従って, 3.1 で記述した $\mathrm{FM}_{\mathrm{HP}}$ 材の摩擦・ 耐摩耗特性の向上は, 硬さや破壊じん性值の向上によって粒 子の脱落が起こりにくくなったことや, 成分添加 $\left(\mathrm{MoO}_{3}\right.$ の 生成)の影響によって摩擦係数が低下したこと, などが原因 の一つと考えられる.

\section{$4.2 \mathrm{Si}_{3} \mathrm{~N}_{4}$ に $\mathrm{Fe}_{3} \mathrm{O}_{4}$ および $\mathrm{Mo}$ を添加した各材料の成分分 析}

前報2)で述べたようにマクロな親油性は, 添加成分のみな らず, 油滴の気孔部への停留によっても変化するが, ミクロ な親油性も, これと同じ気孔部への油滴の停留から説明が可 能かどうかを AFM で調査し検討してみた，すなわち，まず， $\mathrm{SN}$ 材の表面をコンタクトモードで走査した後, 直ちに AC ハンコンタクトモードで同じ場所を走査することにより，表 面形状 (突起物や気孔) を確認した (Fig. 6(a)). そして, カ ンチレバーの先端に油を付着させ, $\mathrm{AC}$ ノンコンタクトモー ドで $3 \mu \mathrm{m} \times 3 \mu \mathrm{m}$ の範囲内を数回素早く走査(走査速度 400 $\mathrm{nm} / \mathrm{s}$ ) させ, SN 材表面上にミクロな油滴を散布させた (Fig. 6(b)).これより, ミクロな油滴もマクロな油滴と同様, 気

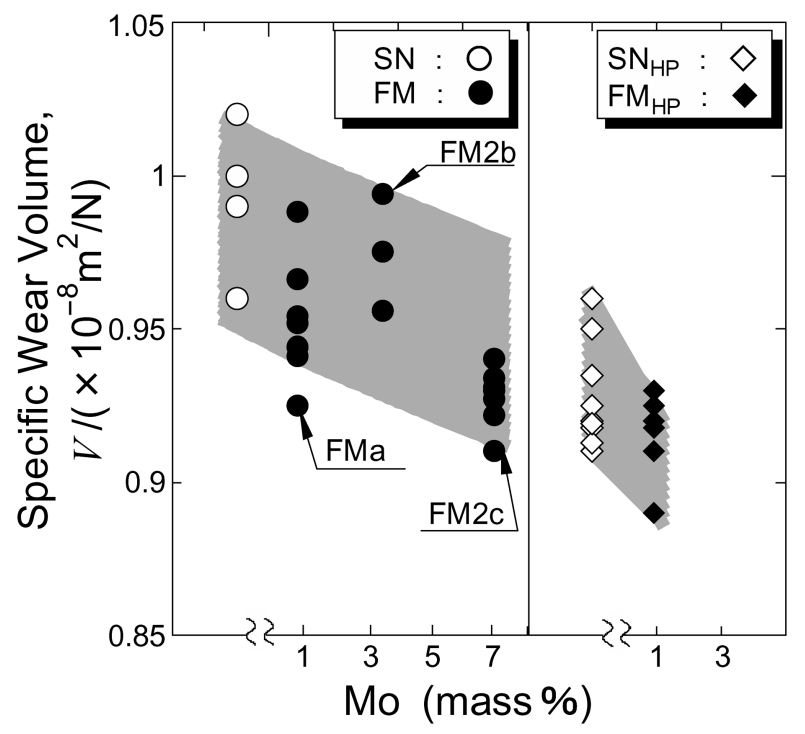

Fig. 4 Change of Specific Wear Volume in Material SN, FM, $\mathrm{SN}_{\mathrm{HP}}$ and $\mathrm{FM}_{\mathrm{HP}}$.
孔部に停留していることがわかる(同図中乃印)。これは, 試 料表面の低い場所はエネルギーも低く, ミクロな液滴が気孔 部に優先的に停留しやすい8)ことに起因しているものと考え られる. 一方で, ミクロな油滴は, 気孔部周辺にも付着して いる. (同図中印).このように, ミクロな油滴は, 気孔部 のみに停留するのではなく表面のあらゆる箇所に付着してお り, ミクロな親油性は, 気孔部などの表面の幾何学的形状の みならず, 表面成分によっても変化する, という点からの検 討も必要である，そこで，表面近傍の成分をまず XRDで調 べた．その結果を Fig. 7 に示す．これより， $\mathrm{FM}_{\mathrm{HP}}$ 材には 第二相として $\mathrm{Si}_{2} \mathrm{~N}_{2} \mathrm{O}$ 相 (同図中矢印)の存在が確認された. また結果は省略しているが，この $\mathrm{Si}_{2} \mathrm{~N}_{2} \mathrm{O}$ は $\mathrm{FMa}$ 材よりも $\mathrm{Fe}_{3} \mathrm{O}_{4}$ の含有量が多い FM1b や FM1c 材(前記 3.2 の Fig. 1 参照)にも認められた. 次に, $\mathrm{FM}_{\mathrm{HP}}, \mathrm{FM} 1 \mathrm{~b}$ および FM1c 各 材の表面および断面を EPMA で面分析 $(50 \mu \mathrm{m} \times 50 \mu \mathrm{m})$ し たところ，FMa 材と同様，Fe および Moの小さな塊(大き さは数 $\mu \mathrm{m})$ が平面上に均一に, しかも点状に分布してい た。 また, 塊が点在する箇所以外にも $\mathrm{O}$ (酸素)濃度の高い部 分が確認された。 ところで, $\mathrm{Si}_{3} \mathrm{~N}_{4}$ に添加した $\mathrm{Fe}_{3} \mathrm{O}_{4}$ は, 焼 結過程においてマトリックス中に酸素を供給し $\mathrm{Si}_{2} \mathrm{~N}_{2} \mathrm{O}$ を生 成させる ${ }^{11)}$. 従って, $\mathrm{Fe}_{3} \mathrm{O}_{4}$ が多ければ酸素供給量も多くな り $\mathrm{Si}_{2} \mathrm{~N}_{2} \mathrm{O}$ の生成量も増えるものと思われる. Fig. 8 は表面 の成分量と $\mathrm{O}$ 量との関係を $\mathrm{FM}$ 材について調べたものであ
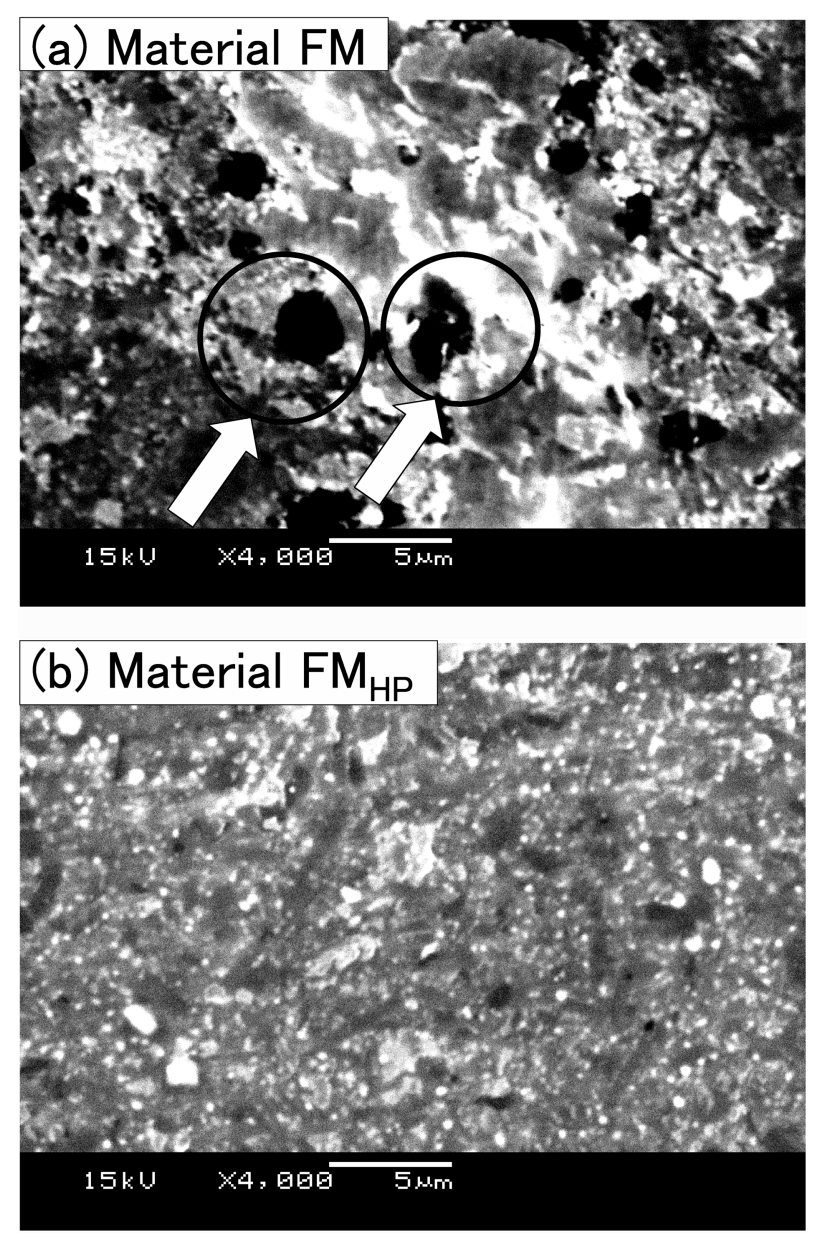

Fig. 5 Wear scar of Material $\mathrm{FM}$ and $\mathrm{FM}_{\mathrm{HP}}$ observed by SEM. 


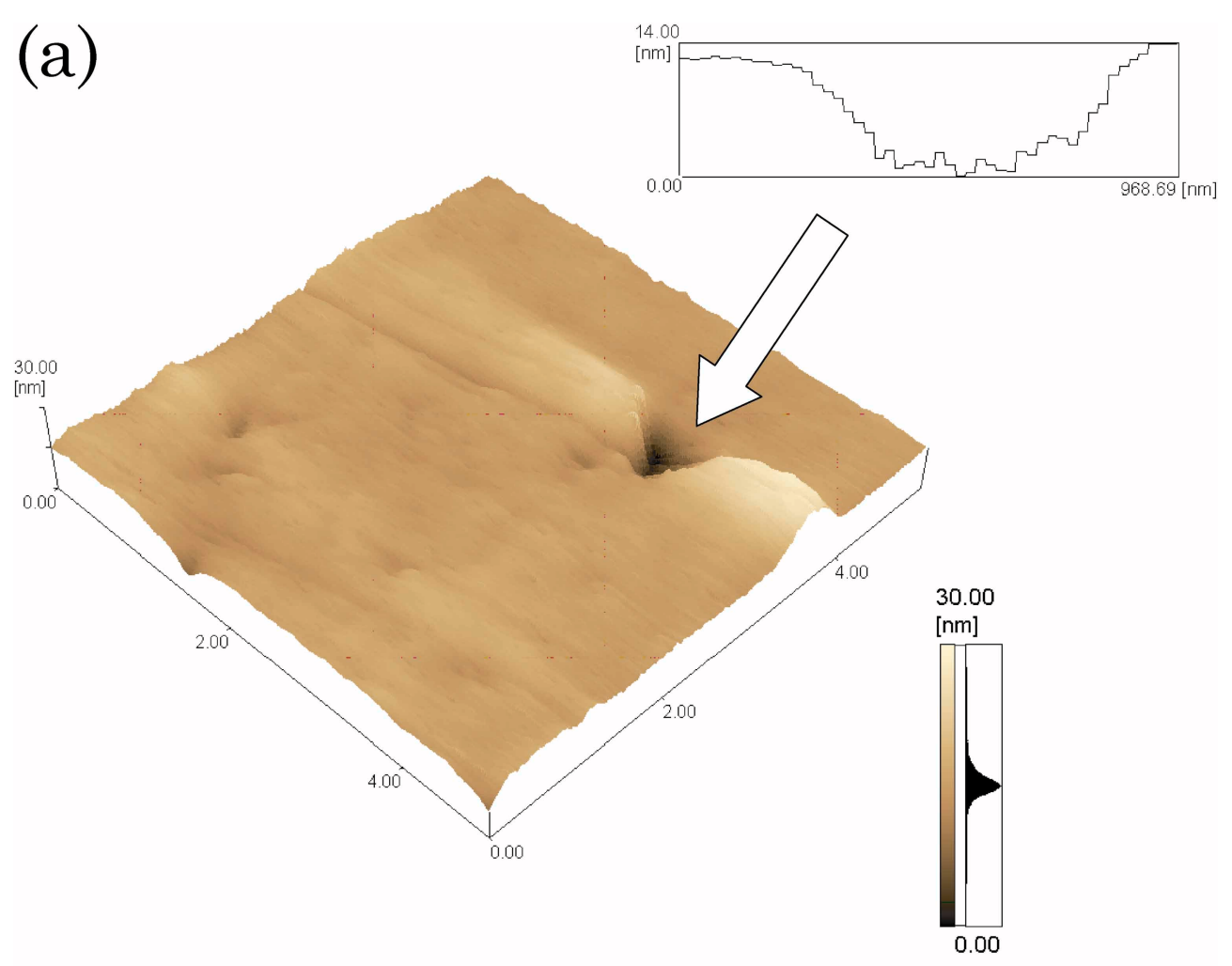

$5.00 \times 5.00[\mu \mathrm{m}]$ Z-Max $30.00[\mathrm{~nm}]$

\section{(b)}

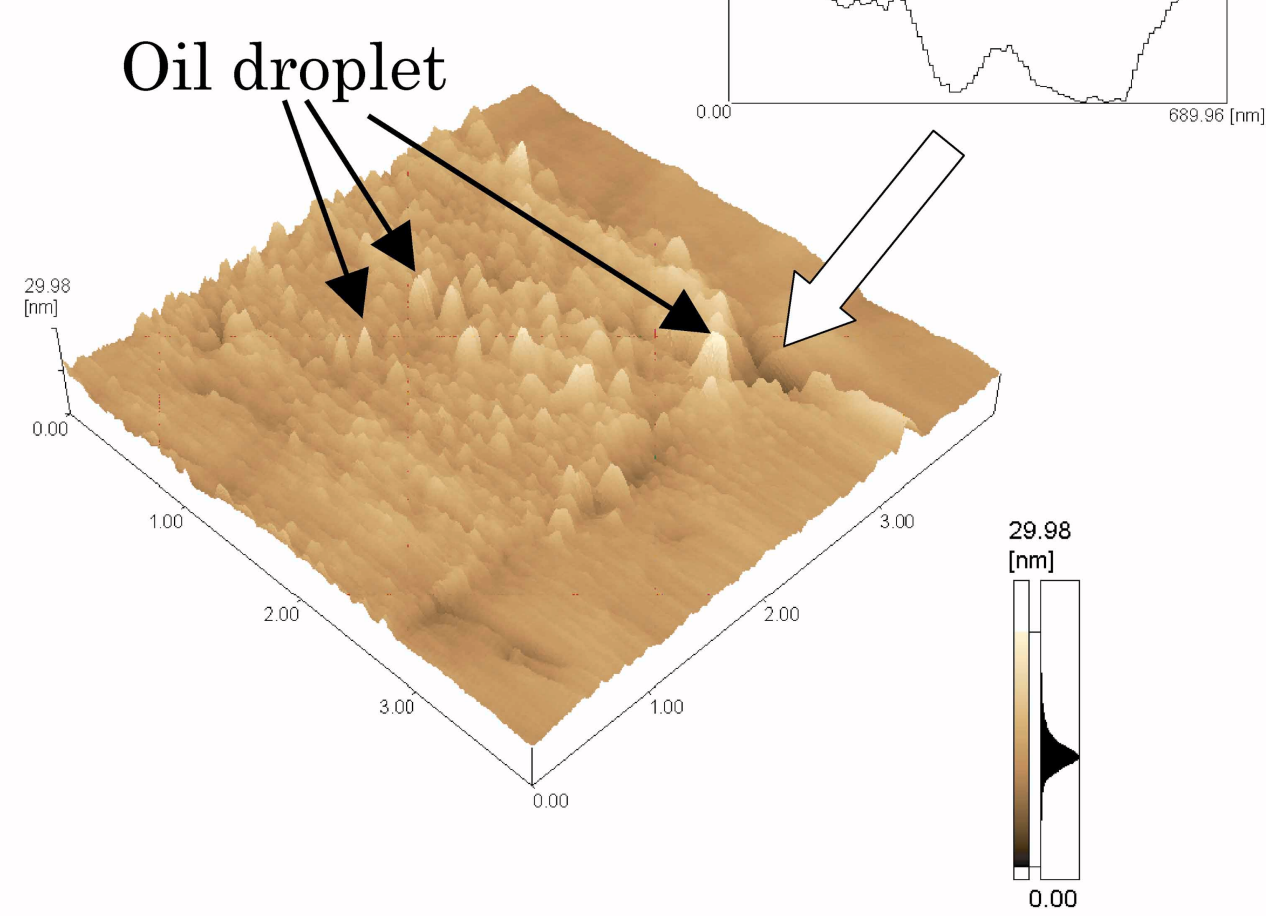

$4.00 \times 4.00[\mu \mathrm{m}] \quad Z-M a x 29.98[\mathrm{~nm}]$

Fig. 6 Stay of oil droplets in blow hole ( (a) before oil droplet dissemination (b) after oil droplet dissemination).

る。な捛同には, $\mathrm{FM}_{\mathrm{HP}}$ 材(表面)の $\mathrm{O}$ 量についても併記 してある.これより, $\mathrm{O}$ 量は, $\mathrm{Fe}_{3} \mathrm{O}_{4}$ の添加に伴い増加して いることがわかる。，一方， $\mathrm{FM}_{\mathrm{HP}}$ 材の $\mathrm{O}$ 量は成分量が同じ である FMa 材に比べて多く, HP 焼結は表面の $\mathrm{O}$ 量にも影
響しているものと考えられる。また，材料最表面に存在する 有機污染物や酸化物の膜も親油性に影響する ${ }^{2)}$ ので, $\mathrm{FM}_{\mathrm{HP}}$ 材の最表面における元素の同定およびその化学結合状態を XPS で調べたところ， $\mathrm{Fe}$ 抢よび Mo はそれぞれ $\mathrm{Fe}_{3} \mathrm{O}_{4}$ 抢よ 


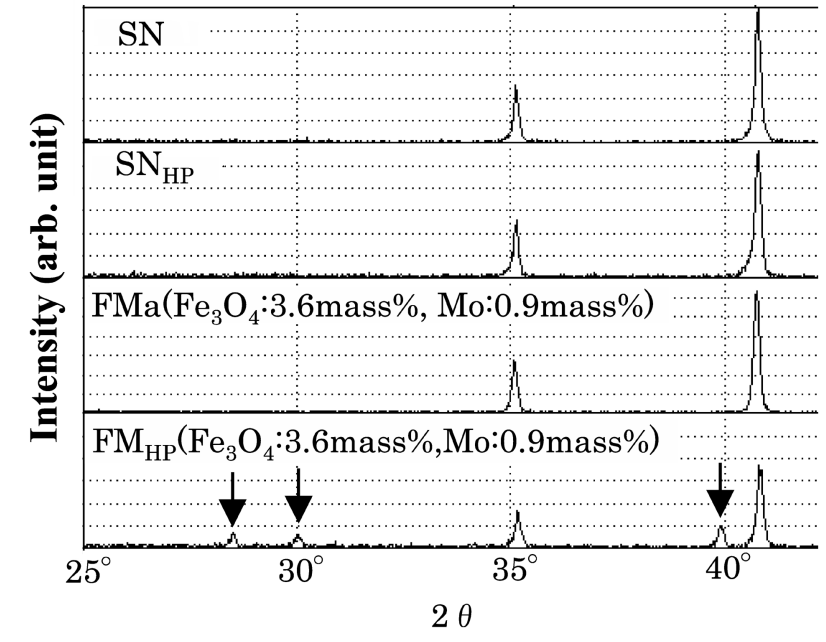

Fig. 7 XRD patterns of Matrial SN, FMa, $\mathrm{SN}_{\mathrm{HP}}$ and $\mathrm{FM}_{\mathrm{HP}}$.

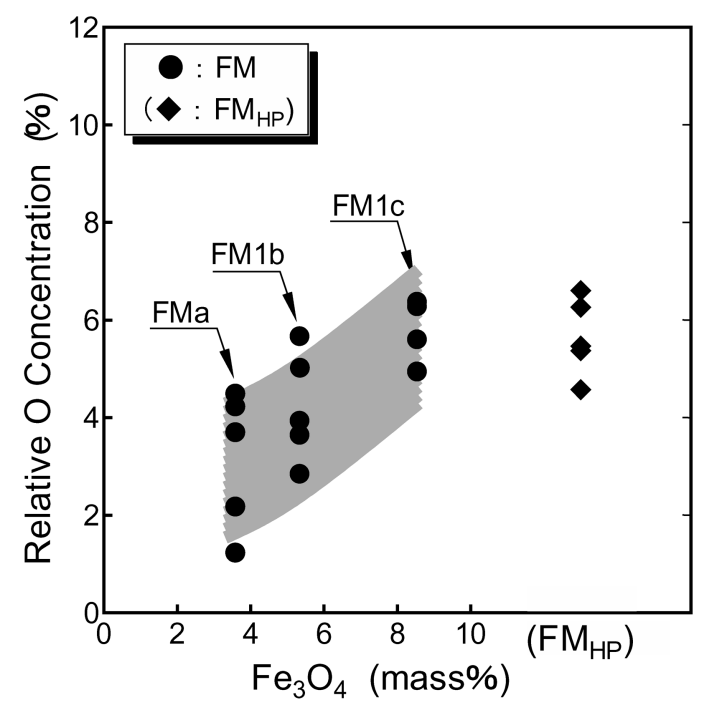

Fig. 8 Relation between additional $\mathrm{Fe}_{3} \mathrm{O}_{4}$ amount and $\mathrm{O}$ concentration in Material FM and $\mathrm{FM}_{\mathrm{HP}}$ by EPMA.

び $\mathrm{MoO}_{3}$ として存在していることがわかった. ところで, $\mathrm{Si}_{2} \mathrm{~N}_{2} \mathrm{O}$ は $\mathrm{Si}_{3} \mathrm{~N}_{4}$ より潤滑油に対する吸着性が高い，つまり 親油性が良いとされている(1)。従って, マクロ抢よびミク ロな親油性が向上した原因の一つには，こうした $\mathrm{Si}_{2} \mathrm{~N}_{2} \mathrm{O}$ の 存在が考えられる.

\section{3 親油性および摩擦・耐摩耗特性に及ぼす $\mathrm{Si}_{2} \mathrm{~N}_{2} \mathrm{O}$ の影 響}

4.2 では, $\mathrm{FM}_{\mathrm{HP}}, \mathrm{FM} 1 \mathrm{~b}$ および FM1c 各材には $\mathrm{Si}_{2} \mathrm{~N}_{2} \mathrm{O}$ が 存在し，それがマクロやミクロの親油性の向上に寄与してい ることを述べてきた，ところで，ミクロな油滴半径は約 80 〜100 nm であり, また, $\mathrm{FM}_{\mathrm{HP}}, \mathrm{FM} 1 \mathrm{~b}$ および FM1c 各材の 表面上での $\mathrm{Fe}_{3} \mathrm{O}_{4}$ 抢よび $\mathrm{MoO}_{3}$ は, 約 $5 \mu \mathrm{m}$ 以上の間隔をお いて存在していることが12)確認されている. 従って, AFM で観察できる範囲内 $(5 \mu \mathrm{m} \times 5 \mu \mathrm{m})$ でのミクロな油滴は, $\mathrm{Si}_{3} \mathrm{~N}_{4}, \mathrm{Fe}_{3} \mathrm{O}_{4}, \mathrm{MoO}_{3}$ および $\mathrm{Si}_{2} \mathrm{~N}_{2} \mathrm{O}$ 各成分が存在する表面の 油滴そのものを測定・評価していることになる.そこで, こ
れら各成分とミクロな親油性との関係についてまとめてみる と, 以下のようになる。 すなわち, FMa 材のミクロな親油 性は, $\mathrm{SN}$ 材とあまり差は認められない(Fig. 1)。これは, ミクロな油滴が $\mathrm{Fe}_{3} \mathrm{O}_{4}$ 抢よび $\mathrm{MoO}_{3}$ に影響されないことを 示唆している. しかし, $\mathrm{FM}_{\mathrm{HP}}$ 材のミクロな親油性は, 成分 添加量が同じである FMa 材のそれより向上(すなわち, 油 滴接触角が低下) している．このことは， $\mathrm{FM}_{\mathrm{HP}}$ 材のミクロ な親油性が，4.2で記述したように $\mathrm{Si}_{2} \mathrm{~N}_{2} \mathrm{O}$ の影響によって 向上したためと考えられる. また, FM1b 抢よび FM1c 材 のミクロな親油性の向上も $\mathrm{FM}_{\mathrm{HP}}$ 材と同様, $\mathrm{Si}_{2} \mathrm{~N}_{2} \mathrm{O}$ の存在 が影響しているものと思われる.

以上より, マクロな油滴の親油性はオーダー的に $\mathrm{Fe}_{3} \mathrm{O}_{4}$, $\mathrm{MoO}_{3}$ および $\mathrm{Si}_{2} \mathrm{~N}_{2} \mathrm{O}$ の存在に影響をうけるが, ミクロな油 滴のそれは $\mathrm{AFM}$ の観察可能な範囲が $5 \mu \mathrm{m} \times 5 \mu \mathrm{m}$ 以内とい うことから, $\mathrm{Fe}_{3} \mathrm{O}_{4}$ や $\mathrm{MoO}_{3}$ よりはむしろ $\mathrm{Si}_{2} \mathrm{~N}_{2} \mathrm{O}$ の影響を うけている可能性が高いと考えられる. なお, $\mathrm{SN}_{\mathrm{HP}}$ 材の油 滴接触角はマクロおよびミクロとも SN 材より低下している が, その理由については現在のところ不明である. 従って, 3.2 で述べたようにミクロな油滴の大きさのばらつきを少な くすれば，ミクロな親油性はマクロなそれと同様に評価でき ると考えられる.

ところで, $\mathrm{Si}_{2} \mathrm{~N}_{2} \mathrm{O}$ は $\mathrm{Si}_{3} \mathrm{~N}_{4}$ に比べて破壊じん性值が低 い12)ため，摩耗量を上昇させる原因になっていると考えら れるが， $\mathrm{FM}_{\mathrm{HP}}$ 材中に存在する $\mathrm{Si}_{2} \mathrm{~N}_{2} \mathrm{O}$ がどの程度摩耗量に 影響を及ぼすのか，については現在のところ不明である.

以上より, $\mathrm{Si}_{3} \mathrm{~N}_{4}$ セラミックスの機械的特性 (とくに強度) を向上させ, さらに, 親油性抢よび摩擦・耐摩耗特性も向上 させるには, $\mathrm{Fe}_{3} \mathrm{O}_{4}$ および $\mathrm{Mo}$ を適量添加させ，それに $\mathrm{HP}$ 焼結させることが有効であることがわかった．しかし, 添加 成分の配合量によっては強度低下を生じることもある：この ことを改善させるには, 粒界の強化や粒子の微小化を図る材 料の設計やプロセス技術の制御・工夫が必要である.これに 加え, $\mathrm{HP}$ 焼結によって $\mathrm{Si}_{2} \mathrm{~N}_{2} \mathrm{O}$ が生成する原因やメカニズ ムについても, 今後の主要な検討課題である.

\section{5. 結言}

$\mathrm{Si}_{3} \mathrm{~N}_{4}$ セラミックスの機械的特性のうち, とくに強度の向 上を図りつつ, 親油性および摩擦・耐摩耗特性の向上を目指 し, $\mathrm{Fe}_{3} \mathrm{O}_{4}$ および $\mathrm{Mo}$ を添加した $\mathrm{Si}_{3} \mathrm{~N}_{4}$ を $\mathrm{HP}$ 焼結により作 製し，それを常圧焼結により作製したものと比較・検討し た. その結果, 以下のことがわかった.

(1) $\mathrm{Fe}_{3} \mathrm{O}_{4}$ および $\mathrm{Mo}$ を添加した $\mathrm{Si}_{3} \mathrm{~N}_{4}$ を $\mathrm{HP}$ 焼結するこ とで, 曲げ強度, 相対密度, 硬さ抢よび破壊じん性值, はい ずれも向上した. とくに曲げ強度は約 2 倍, 相対密度は約 $4 \%$ 以上向上した.

(2) $\mathrm{Fe}_{3} \mathrm{O}_{4}$ および $\mathrm{Mo}$ を添加させ, $\mathrm{HP}$ 焼結した $\mathrm{FM}_{\mathrm{HP}}$ 材 のマクロおよびミクロな親油性は $\mathrm{HP}$ 焼結しないもののそれ より向上した。 その原因は, 成分添加による $\mathrm{Fe}_{3} \mathrm{O}_{4}$ や $\mathrm{MoO}_{3}$ の生成および $\mathrm{HP}$ 焼結により生成した $\mathrm{Si}_{2} \mathrm{~N}_{2} \mathrm{O}$ の存在による 影響が考えられる.

(3) $\mathrm{Fe}_{3} \mathrm{O}_{4}$ およよ゙ Mo を添加させ, $\mathrm{HP}$ 焼結した $\mathrm{FM}_{\mathrm{HP}}$ 材 
の摩擦・耐摩耗特性は HP 焼結しないもののそれより向上し た，その原因は，硬さや破壊じん性值が上昇し摩耗量が低下 したことによるものと考えられる.

\section{文献}

1) H. Kita, T. Iizuka, T. Hirai, T. Murao and Y. Unno: Ceramics 36 (2001) 438-440.

2) T. Tokuda, K. Kato, R. Wang and M. Kido: J. Japan Inst. Metals 67 (2003) 348-353.

3) T. Kinoshita: J. Japan Inst. Metals 59(1995) 862-868.

4) M. Chu, S. Sato, Y. Kobayashi and K. Ando: Jour. Jpn. Soc. Mech. Eng. 61(1995) 933-939.
5) R. Wang, M. Kido, T. Tokuda, K. Kato and S. Nakanisi: J. Japan Inst. Metals 67 (2003) 404-409.

6) M. Iwasa and M. Kinoshita: Osaka. Industry. Technical. experiment station, Japan 39(1988) 135-140.

7) T. Kinoshita: J. Japan Inst. Metals 44(1995) 1053-1059.

8) R. Wang, M. Takeda, K. Mukai and M. Kido: J. Japan Inst. Metals 65 (2001) 1057-1065.

9) M. Iwasa and M. Kinosita: Ceramics. Ceram. 24(1989) 144156.

10) T. Iizuka, T. Murao, H. Yamamoto and H. Kita: J. Ceram. Soc. Japan 109(2001) 699-703.

11) H. Kita, T. Iizuka, K. Osumi and T. Hirai: J. Cram. Soc. Japan 111 (2003) 59-66.

12) K. Kato, T. Tokuda, T. Dote and M. Kido: Proceeding the $9^{\text {th }}$ of Young Ceramist Meeting in Chugoku and Shikoku (2002) pp. 85-87. 